\title{
Towards enhancing local citizen participation in Uganda
}

\author{
David Mwesigwa
}

Lira University, mid-north of Uganda davidmwesigwa22@gmail.com

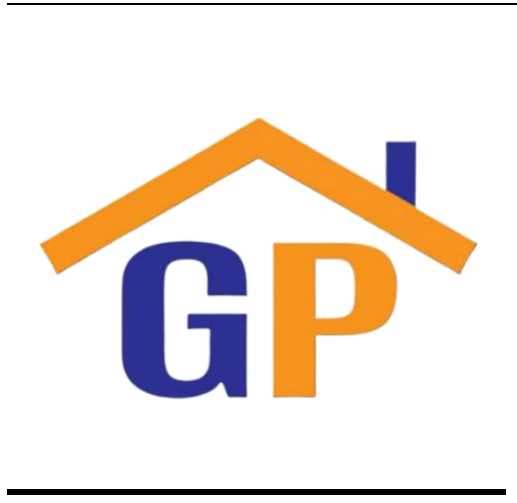

Article History

Received on 18 February 2021

Revised on 24 February 2021

Accepted on 28 February 2021

\begin{abstract}
Purpose: This paper aimed to propose an alternative model of enhancing citizen participation in Uganda.
\end{abstract}

Research Methodology: This paper's central approach was to review obtainable theoretical and conceptual writings on citizen participation in Uganda and other parts of the world. The literature review is the gathering of information from obtainable resources such as educational journals and statistical periodicals. The approach has been demonstrated to be very effective and can be applied to any research process stage.

Results: Citizen Participation encourages marginalised groups to be organised in structures under their control; brings knowledge of their social environment and process to the local government agenda in a way that no other structure can as well as fostering self-reliance. Limitations: This study took a desk research and the actual opinions from selected citizens may be parallel to the conclusions obtained in this review.

Contribution: The study can be used for local government managers implementing community-driven projects.

Keywords: Citizen participation, Policy implementation, Stakeholders, Bureaucrats, Local leaders

How to cite: Mwesigwa, D. (2021). Towards enhancing local citizen participation in Uganda. Dynamics of Politics and Democracy, 1(1), 15-28.

\section{Introduction}

Citizen participation has become an essential element in present-day governments' management and operation (Mwesigwa, 2013). It is so essential that it guides and dictates both the course and quality of local governance. Citizen participation leads to improved relations between civil servants, elected representatives and the citizenry through better engagements (Liao \& Ma, 2019:1825). Based on the principle of devolution of authority, the formation of local governments entrusts more powers and influence to local citizens. This review on "citizen participation in Uganda" is an endeavour aimed to enhance citizen participation both as an ingredient and as a process to attaining sustaining sustainable governance. Consequently, the review addresses the scale of citizen participation in Uganda and delves into its significance. By analysing citizen participation in Uganda, the review considers whether citizen participation is, indeed, effective thus far. This review's background is organised on four key perspectives, viz., historical, theoretical, contextual and conceptual. The historical perspective presents evolution of what I construed as contemporary citizen participation in Uganda traceable from the immediate post-independence era to the present. The theoretical perspective focuses on basic assumptions about the review. The contextual perspective exhibits the ability of the citizen participation as a univariate. And, the conceptual perspective demonstrates the main elements of review and their inter-relationships.

The primary logic for the occupation of Uganda, by the British colonialists between 1894 and 1962, is believed to have been the abundance of natural resources which the British took advantage of (Mwanika, State, Atekyereza \& Österberg, 2020). Furthermore, it is assumed that Uganda took longer before realising self-governance due to a dearth in citizen participation. By inference, citizen participation emerges as one of the most significant factors for realising what a small group or an 
individual cannot achieve. The idea of citizen participation is presented as a precondition for attaining effective local governance. By 1963, an extremely centralised state became decentralised resulting the transfer of power, functions and services from the central government to local councils (Musenze \& Thomas, 2020). Decentralisation was regarded as an alternative to a number of the challenges affecting governance and as a path to enhancing poverty reduction (Muriisa, 2008:85). According to Byekwaso (2010:519), decentralisation became the foundation on which government tried to encourage citizen participation, improved service delivery and poverty reduction.

The basis of Uganda's decentralisation policy was grounded on the necessity to increase citizen participation. This stride was selected because the Independence Constitution recognised a decentralised structure merging federal governance in the Kingdom of Buganda, semi-federal status in Ankole, Bunyoro and Toro well as the territory of Busoga (Moehler, 2006:277). Also, the Independence Constitution provided for councils to be recognised in Acholi, Bugisu, Bukedia and Karamoja. Every strategy was aimed to introduce a system of citizen participation in local-level undertakings. Nonetheless, the Independence Constitution was abolished in 1966 and swapped with a Republican Constitution, giving way for re-centralisation and constrain on local authorities (Corrigant, 2017). The coup of 1971, coordinated by Idi Amin, melted district councils along with urban administrations, recognising only provincial administrations. A number of governors whom Idi Amin selected required understanding and proper awareness of citizen participation and council restraint, and local citizen management (Katusiimeh, 2015:86). During his second tenure (1981-1985) Milton Obote remained reluctant about re-establishing citizen participation (Mazurui, 1970:539). Hence, the re-introduction of democratic citizen participation symbolises a social contract with the people of Uganda and is one of the core characteristics of the 1995 Constitution.

The National Resistance Movement (NRM) government was stimulated to decide so as to provide assurance, to the people of Uganda, that democratic citizen participation was a priority (Makara \& Svåsand, 2009). That idea was inspired by acknowledging that, providing a people have the chance to express their own ideals and progress, that society will control their fortune (Manyak \& Katono, 2011:10). In reaction to that respect, one of the choices made in 1986 was to form, from the village to the district, Resistance Councils and Committees as organs for policy-making and implementation (...). The Government of Uganda launched the decentralisation policy, on 2 October 1992, with explicit aims of setting off citizen participation and improved service delivery (Otafiire, 2007). Since then, the term "citizen participation" was acknowledged and treasured, and has remained prominent as one of the strategies to effective public sector management (Nakayi, n.d).

A number of bodies have documented citizen participation; for example, World Bank and the international monetary fund (IMF), academia, governments and civil society organisations (CSOs) as a means of achieving successful local economic development (Przeybilovicz, Cunha, geertman, leleux, Mchels, Tomor, Webster \& Meijer, 2020). Each of the bodies mentioned above ascribe significance to the supremacy of citizen participation in the achievement of a number of development programmes and or projects (Gaber, 2019:189). Achieving the Sustainable Development Goals (SDGs) necessitates dynamic citizen participation as an indispensable route to guaranteeing effective programme and or project implementation. Consequently, citizen participation becomes one of the key channels to effective policy implementation at local government (Fisher \& Fukuda-Parr, 2019:376). Drawing on Marxism which underscores the significance of local governments on the basis of present-day entrepreneurship (Editorial Board, 2008:539), the architects recognise interests that are articulated through local governments by revolving around the local state and capitalist reproduction in addition to collective consumption and working-class interests. These claims underline citizen participation's significance though based on uneven relationships (Michels \& De Graaf, 2017:876). The Marxists further spin their ideas around inter-governmental relations as well as the constraints on local governments. This is not to refute the significance of class consciousness as a pre-condition for manipulation of the grassroots and so the blend of a number of Marxist views exposes the magnitude to which the incentive for and implementation of policy should be based on effective citizen participation (Bohn, 2019). 
It is central for one to be cognisant of the different philosophies and attitudes, unequivocal or implied, to policy and the government. Despite everything, disciples of Marxists are apprehensive with social actions and mutual benefits in particular historic situations. By inference, assessing the efficacy of citizen participation becomes essential to present studies. While the economic interpretation of local governments emphasises both public choice and collective consumption, the node between public choice and collective consumption requires a dynamic community, at every level, which is mindful of its needs and how to harness them. Even if the neo-Marxist views appear to inhibit the variance between realism and oratory, the economic interpretation presents a precise idea in relation to the significance of citizen participation (Gare, 2020). The economic interpretation further advances key concerns, viz.; public responsiveness to individual preferences, the demand and supply of public goods, as well as the theoretical and practical problems. These concerns are vital elements though prominence is put to the efficacy of citizen participation. This clarifies why most ideas offered by the economic interpretation indicate the efficacy of effective citizen participation (Hossain \& Roy, 2019:828).

The liberal democratic theory supports local governance as one of the methods to organising local administration of public services (Reidy, 2020). The academic foundation to liberal democrats underscores the efficacy of local consensus as one of the potential means to realising national consensus. This position is essential to citizen participation in the administration of local undertakings, including in other African countries (Connolly, Klofstad \& Uscinski, 2020). However, enabling citizen participation necessitates transparency concerning whether citizen participation is pertinent since the liberal democrats put up with the need for national consensus. The liberal democrats have been recognised for drawing local consensus to local citizens (Rosen \& Painter, 2019). Yet, the thinking behind the liberal democratic theory does not isolate the consequence of local government experience from other experiences such as those attained through civil society. If possible, those experiences would be seen as prime elements, notwithstanding the vital role they make to guarantee an effective national and local consensus (Dodeigne, Jacquet \& Reuchamps, 2020). One of the means by which the above ambiguity can be understood is by considering citizen participation's efficacy.

Every citizen involved in the process of executing devolution should be devoted (Fridy \& Myers, 2019). The structures of local governance present a set of three dimensions, viz., the shaping of policy outcomes, the interplay of elements within the total political system, and the problem of illusory decentralisation. The Leviathan model presents a situation where rigid self-centred administrators and representatives pursue their own interests instead of citizens (Campe, 2020). The two groups seem to be critiqued for building a local dominion incapable of tolerating citizen participation to set in. Notwithstanding that paradox, Uganda's local governance is hinged on the values of citizen participation among the local people who had hitherto been omitted (Musenze \& Thomas, 2020). This review took the Marxist theory so as to establish means to enhance citizen participation in Uganda. One of the strategies adopted was the fragmentation of bigger districts into small districts in addition to employment of fresh graduates to execute services such as agricultural extension and community development (Bulthuis, Kok, Amon, Agyei, et al., (2021). To enhance the degree and implementation, leaders in local governments were sensitised concerning how to monitor policy as well as delivery of services in their areas of jurisdiction (Musenze \& Thomas, 2020). Also, efforts were made to incorporate local government plans and budgets so as to improve budgetary efficacy. That incorporation required Uganda and its constituent local governments to act in accordance with the government policy framework (Mpiima, Manyire, Kabonesa \& Espiling, 2019). Moreover, the previously marginalised groups, mainly the women, the youth and people with disabilities (PWDs), were brought into the mainstream local government programmes (Bedigen, Mdee, Temlong, Thorley \& Tshomba, 2020).

Despite the development mentioned above interventions, it remains uncertain whether citizen participation plays any significant role in local governance (Benstead, 2019). For instance, issues concerning policy implementation have been detached from the local citizens in addition to a number of local government policies being presented in foreign languages (Dixon \& Elson, 2019). This review maintains that public policy entails close partnership between interested parties in realising effective citizen participation. Hoima district's consideration reveals that from 2000, there have been several debates about the strategy hitherto envisioned. This condition suggests that not a many studies have 
been undertaken on enhancing citizen participation in spite of its significance. Citizen participation was expected to be vital at the various levels of the local government structure. At village level, every member residing in a village aged 18 and above is considered to be a member of that village council. However, as one moves up the local government structure, the level of citizen participation becomes more indirect. For instance, at sub-county, town council, municipality or district level, only a few elected councillors control policy affairs (Tromp \& Datzberger, 2019). While it is expected that those councillors apply a consultative approach, individual discretion is a key driver for most policy frameworks.

\section{The problem}

This paper's central emphasis is the prevalent variant of low citizen participation in Uganda, which is a key contributing aspect to poor service delivery in the country. As a consequence, there are signals that the situation, in Uganda, is structural in nature as a number of public businesses are organised through indirect participation for convenience. This situation is challenging the significance of local governments and demands immediate consideration. This paper examines ways by which citizen participation can be enhanced.

\section{Purpose and objectives of the study}

The purpose of this paper is to examine the means of enhancing citizen participation in Uganda. In realising this purpose, three questions will be answered: (a) what is citizen participation and what are the forms of citizen participation? (b) What issues affect citizen participation in Uganda? And (c) in what ways can citizen participation be enhanced in Uganda?

\section{Research methodology}

This paper's central approach was to review obtainable theoretical and conceptual writings on citizen participation in Uganda and other parts of the world (Juntunen \& Lehenkari, 2021). The literature review is gathering information from obtainable resources such as educational journals and statistical periodicals (Yang, 2020). The approach has been demonstrated to be very effective and can be applied at any research process stage.

\section{Outcomes and discussions}

\section{The idea of citizen participation}

Citizen participation is not novel, nor is it narrow; it is worldwide, continental, regional, national and local (Arnstein, 2019). It symbolises a truly transforming exercise of state authority which relates to a rise in opportunity and gravity of subordinate involvement, resulting in the popular and practical allocation of public resources (Ianniello, Lacuzzi, Fedele \& Brusati, 2019). It embodies empowering citizens to get involved in government processes, monitoring resources, and resolute activities for direct impact on government decisions. In this review, citizen participation appears to be associated with citizen empowerment, as a fundamental right of the people as well as an impetus for joint commitment in development processes. This view is held by a number of scholars (such as Maryunani, 2019). Citizen participation, for that reason, presents an all-inclusive society incorporating every citizens' potential and sustainable benefits. Therefore, a general agreement exists on the belief that citizen participation encompasses opportunities in which citizen influence and control over decisions affect them (Carvalho, Pinto-Coelho \& Seixas, 2019). Nevertheless, this observation does not distinguish citizen influence from citizen participation, nor does it define each's necessary level. Indeed, the observation presents a view that citizen influence is attached to control, which is then similar to citizen participation. That justifies why a number of scholars, such as Carvalho et al (2019), suggest that citizen participation is concerned with realising authority to influence decisions which affect community livelihoods.

Citizen participation involves sharing, by the citizens, in the benefits of development, an active contribution of citizens in the development and their participation at every level (Forrest, Trell \& Woltjer, 2021). The views regarding citizen participation seem to converge towards a common notion of "citizen influence and or control". This control encourages and empowers (local) citizens at every level of government and creates an environment where the citizenry can play a part in the governance 
of their area (Hambleton, 2019). This view is true as long as the leaders and the led are both prepared and willing to do the collective thing. On the contrary, other scholars, such as Falguera, Prieto-Flores and Torruella (2020), note that citizens may not value public affairs nor do they hold regular consultation with their leaders. In spite of this void, consultation remains one of the key elements of effective citizen participation. Dearth of regular consultation causes a huge vacuum between the two groups in local participation (the leaders and the led). This is continuous as long as it is believed that citizen participation increases the level to which every citizen can enjoy free interaction with one another. Thus, citizen participation ascends from a combination of 'push' by the community and 'pull' from the existence of an opportunity for the community to cooperate.

In this review, the definition of citizen participation is inclined to Simplican (2019), who views the term as an all-inclusive approach covering every aspect of those benefiting directly or indirectly from the anticipated outcomes. Simplican further notes that citizen participation encompasses "taking an active contribution in the affairs, directly or not directly, without any coercion from the external environment". Moreover, Simplican's review links direct participation to direct democracy while linking indirect participation to representative democracy. Through that link, international institutions have emphasised the ingredient of citizen participation as one of the elements of dealing with formal hurdles within the local government system (Lang, 2020). This emphasis may be right though it may not be clear whether it can lead to successful local governance. A close analysis of obtainable literature reveals a number of affirmative outcomes associated with citizen participation.

\section{The outcomes of citizen participation}

In this review, a number of outcomes associated with citizen participation listed, namely:

One, citizen participation encourages marginalised groups to be organised in structures under their control (Kim \& Sun, 2020). Encouraging marginalised helps citizens to grow in a balanced way. In the case of Uganda, marginalised groups include, but are not limited to, women, PWDs, the elderly, children, and people living with HIV/AIDS (PLWAs). That is why the Government of Uganda made an effort to bring all the formerly marginalised groups into the fold. This was pursued through a deliberate emancipation strategy covering education, health services, agriculture, water and sanitation. It involves taking personal and social responsibility to collect information, reflect and analyse the problems, apply indigenous knowledge and local experience, increase knowledge and skill, in addition to organising action groups to participate and manage resources (Andrew, Richards, Jacobs, Ivy \& Lawson, 2020). Personal and social responsibility carries with it the notion of accountability, which is still a big challenge in local governments in Uganda. Nonetheless, the application of indigenous knowledge and local experience could be a significant ingredient of reinforcing the implementation process.

Two, it fosters self-reliance, strengthens women's position and spearheads progress in gender relations towards equality (Forsberg, 2019). Indeed, no contemporary development initiative is likely to succeed without due regard to the notion of gender relations and, precisely, women inclusion. Once gender relations are firmly recognised, sustainable development becomes a reality (Matarrita-Cascante, Lee \& Nam, 2020). Gender relations are fundamental in local participation since the notion of gender equality will be recognised at all levels of the policy. The notion of "citizen" is essential among human societies because of the positive outcomes that are linked to its presence. For instance, through citizen participation, anti-poverty programmes can easily be realised (Nguyen, Giang, Tran \& Do, 2021). This suggests that where there is effective citizen participation, the scale of poverty can easily be reduced in that society, unlike where citizen participation is lower or even absent (Feng \& Li, 2020). That is why governments such as Uganda treat democratic citizen participation as one of the direct 'engines' through which they can lead their citizens into the 'path' to prosperity (Rosen \& Painter, 2019). Indeed, the suggestions of Khurshid (2020) may not be realised unless the decisive citizens are committed to allowing the trickle-down effect of local empowerment to be actualised. After all, the two scholars (Khurshid, 2020) seem to treat all societies as uniform, yet there are significant variations, such as sociocultural dynamics, which influence the perceptions and readiness of citizens. 
Three, citizen empowerment, which is associated with citizen participation, can easily be guaranteed in society while increasing the availability, cost effectiveness and user satisfaction of public programmes and projects (McKnight, Gribbs, Sanders, Cope, Jackson \& Park, 2019). It is nonetheless not clear, here, whether resources can be available automatically or whether the cost can be self-regulated without the contribution of other environmental factors, such as market conditions. In addition, none of the above scholars has indicated any dependable tool to measure public satisfaction of public programmes and projects among local governments.

Four, effective citizen participation can be used to enhance local project efficiency, effectiveness, selfreliance, coverage and sustainability (Ianniello, Iacuzzi, Fedele \& Brusati, 2019). The outcomes presented by Ianniello et al (2019) could be positive but, after more than two decades, one wonders whether their expectations are still applicable in this era. Therefore, in spite of the view that arguments are closely connected in terms of spreading sustainable local development among citizens, especially individuals in the country, it is still a challenge for one to separate theory from reality. For instance, global conditions have become more decisive where more human populations have become interconnected socially and citizenry (Wagenaar \& Wenninger, 2020).

Five, soliciting the participation of all citizens deepens the level of decentralisation to the grassroots, since all categories have an opportunity to take part in affairs affecting them directly or indirectly (Basiru, 2021). Uganda has been implementing decentralisation for more than two decades now but it still remains unclear whether the decentralisation policy has increased the opportunities of the grassroots to get involved in public affairs. It is further not clear whether the technical officials and elected staff do not collude in order to satisfy their own private desires (Ragauskas \& Thames, 2020). Six, it enables a community to address its felt needs through self-help projects and to realise grassroots democracy; to ensure fair and equitable distribution and access to resources; and to obtain maximum utility to local resources for effective community development (Dulhunty, 2020). Other scholars perceive citizen participation as an essential conduit for the poor and marginalised peoples to assert their position in local government decision-making. However, according to Rosen and Painter (2019), citizen participation is mainly justified on four fronts: first, it encourages marginalised groups to be organised in structures under their control; second, it brings knowledge of their social environment and process to the local government agenda in a way that no other structure can; third, it fosters self-reliance - an attitudinal quality likely to engender solidarity, caring and the sharing of a collective identity; and fourth, it strengthens women's position, providing for the articulation of their points of view and, thereby, spearheading progress in gender relations towards equality as assessed by women themselves.

\section{Forms of participation}

A number of forms of participation can be adopted by local governments, namely; traditional participation, customer-oriented participation, consultative participation, and innovative participation (Falanga, 2020):

\section{Traditional participation}

Traditional participation includes public meetings such as village or Local Council 1 (LC1) members, usually held in trading centres; question-and-answer sessions; and consultation documents (Singh, 2020). Public meetings ought to be the most popular among all the traditional approaches to citizen participation involving District Council sessions and District Technical Planning Committee (DTPC) meetings. In local governments, public meetings could well be exploited as one of the significant means to ensure citizen participation.

\section{Customer-oriented participation}

Customer-oriented participation involves customer satisfaction surveys aimed at establishing the level of approval members have regarding a particular service, such as universal primary education. Others involve opinion polls, selected using a random sample population, that are aimed at determining the attitude of local members (Ahm \& Rho, 2021). Moreover, complaints procedures and suggestion schemes can be conducted using suggestion boxes placed at public offices for citizens to route their displeasure and possible remedies. It is highly doubtful whether customer-oriented participation, 
through satisfaction surveys and opinion polls, has ever been applicable in less-developed countries. In some selected cases, it may only be possible to find suggestion boxes that may not carry any significance for the ultimate position held by senior management, though visible at some sub-national headquarters.

\section{Consultative participation}

Consultative participation includes interactive websites using such fora as Twitter or Face book in areas where there is electric power or other forms of energy. Another type of consultative participation involves citizens' panels allowing randomly selected members to interface with service providers as a mode of taking stock of the successes and failures registered over time. Consultative participation also involves focus groups which allow local members to brainstorm the quality of a particular service provided by the local government. Consultative participation also includes referendums that allow concerned members to indicate their position regarding a controversial issue or policy direction (Deligiaouri \& Suiter, 2021). Some few countries in Africa have only conducted few referenda at national level. The use of interactive websites demands appropriate infrastructure, and the availability of energy and human ability, which may not be present in most district departments. Citizens' panels in the form of barazas may only be experienced in a few districts and at a slow tempo (McGovern \& Thorne, 2020). The slowness could, in part, be due to the scarcity of financial resources and the general reluctance among local officials to interface with and have the local members hold them accountable. Therefore, the success of barazas among local governments becomes problematic to assess. Focus groups may scarcely be adopted by heads of departments and district executive committees and may fail to be deeply entrenched in the system.

\section{Innovative participation}

Innovative participation includes, but is not limited to, four possibilities (Binnema \& Michels, 2021): Environmental fora, which include professionals and activists that come together in order to find practical ways of overcoming an environmental disaster as well as environmental preservation and conservation (Zhang \& Lee, 2020). In essence, such fora would be fundamental among local governments since their adoption at a time when the global environmental trends are changing rapidly would enhance sustainable and implementation in Uganda as long as citizens are committed and patriotic. Nonetheless, the absence of committed professionals and activists at the local level may become a serious challenge. Visioning exercises tend to allow members to make projections into the future of their local areas regarding different community-based projects. By implication, local governments such as Uganda would be required by law to prepare a three-year development plan incorporating the plans of lower local councils under a highly participatory and bottom-up process in line with section 36 of the 1997 Local Governments Act. It would then be held that the preparation of development plans as well as and implementation would take, among others, visioning exercises. However, this exercise's success would undoubtedly call for citizens who can make projections into the future of their local areas concerning community projects.

If adopted in Uganda, planning cells would allow citizens to indicate their short-term, medium-term, and long-term expectations. Lower local councils would be construed as planning cells while the higher councils would attract the central government's resources and attention to elect their leaders (Yuan \& Schraufnagel, 2020). The lower councils might have difficulty in convincing the centre to allocate such resources amidst the demands of crucial national programmes and projects. In essence, therefore, the members who should indicate different community expectations among the higher councils could thus have given up.

Citizens' juries, which involve local elites making critical assessments, are pertaining to various departments and units' performance through an interactive session with service providers and/or technical officials. Actually, if such juries were adopted in Uganda, they would be very useful in local councils though the local elites' general attitude would not be imposing. Therefore, the scale of innovative participation depends on the willingness by the central government to relinquish powers, which would still be a nightmare in many countries. By implication, where the centre has not devolved significant powers to district local governments, the adoption of innovative participation may not be realised. Analytically, environmental fora could have been an effective means of averting the current 
human made environmental challenges in the districts but they may not be in existence. Such challenges include, though are not limited to, wetland reclamation and greenbelt destruction (Hadden \& Bush, 2020). It is, nonetheless, not clear whether visioning exercises are applicable during the district planning and budgeting conferences in local governments. Planning cells which would focus on generating village and parish priorities among local governments require legitimate local councils. Thus, citizens' juries could begin with the higher councils evaluating services provided by different service providers or contractors if citizens were committed.

\section{Challenges to effective citizen participation}

Citizen participation faces numerous challenges which have been identified:

\section{Dominance in favour of local leaders}

Chairpersons together with members of the executive prefer producing brief notes mainly giving the state of the village rather than village priorities to the parish councils. In addition, chairpersons who convene village meetings have continued to demonstrate low capacities to mobilise residents, focus meetings, organise meeting venues, target major social citizens and ensure proper documentation of meeting proceedings. Therefore, citizens end up not participating in public affairs owing to lack of empowerment (Gohori \& Van Der Merwe, 2021). The weaknesses pointed out indicate serious challenges facing lower-level councils although they do not show whether those weaknesses affect the higher local government councils such as the district and the municipality.

\section{Commercialisation of citizen participation}

Disempowerment of people through bribery for participation and handouts of free money, commonly called facilitation and reimbursements, is a serious factor that negatively impacts citizen participation and implementation (Townsend, Chen \& Wuthrich, 2021). Nonetheless, the scholar seems to make a general observation without indicating whether bribery affects citizen participation in local councils or CSOs. After all, most local councils and/or councillors may not have the resources for bribing citizens to induce them to participate.

\section{Marginalisation of women}

Women have not yet actualised their influence in local councils because of unfair rules, practices, and local councils' unfriendly organisational cultures. Further, most women are afflicted by the "thanking syndrome" and have been relegated to the role of supporting male councillors in most local councils. The views here may be questioned since a lot of changes have taken place since their publication about, two decades ago. Women may have seen much local government information being passed through personal networking rather than the official channels (Sobande, Fearfull \& Brownlie, 2020). It is, nonetheless, not clear, as it seems more evident, that Sobande et al made an observation from a biased position because she did not indicate whether all local government business is channelled through such networks. Women are often looked down upon and they tend to be more frequently interrupted during local council sessions. The UPPA report falls short of expressing fundamental views such as whether the "looking down" on women had any significant impact on their participation or whether those interruptions were directed only at women and no one else.

\section{Language barrier}

Most rural councillors are not well versed in the English language, which affects their participation (Sobane et al., 2020). The scholar does not reveal whether English was a problem at all local government levels, from the district down to the village. Even if that were so, the assumption that local languages are often used in lower local councils would not be relevant. This is because lower local councils in Uganda use local languages during all council sessions and, therefore, the English language does not present a challenge as hypothesised by Sobane et al. One may only support them on the grounds that there are local councils in which a multiplicity of languages are used, in particular the urban councils, and in their case English becomes the generally accepted medium of expression during all council sessions.

\section{Socio-economic background and central government's reluctance}


Conflicts of interest, socio-economic background, and the central government's reluctance to cede power and resources are still evident (Patrucco, Agasisti \& Glas, 2020). These observations could constitute serious challenges to citizen participation in local councils, although what they reflect could have been overtaken by events. One would support the factors pointed out; however, as long as their statistical effect has not been made, language, culture, interests and values can easily be viewed as merely theoretical.

\section{Cultural factors}

Cultural limitations affect citizen participation in addition to the interests and values that particular citizens attach to local participation; some citizens could be willing to render support while others remain reluctant to do so (McCandlish \& McPherson, 2020). The scholars made a significant point here but failed to point out some of those cultural limitations which affect citizen participation and whether those factors were still valid in present-day societies. The scholars further failed to point out whether cultural limitations have any effect in Ugandan communities too.

\section{High levels of corruption}

Local governments have been identified as one of the most corrupt public institutions in Uganda. This is mainly on account of their failure to provide accountability for public resources (Rochlitz, Kazun \& Yakovlev, 2020). Members of the public have thus accepted the vice of corruption as a way of life. This cannot only lead to economic decline, social disharmony and political instability, but can also affect the level of citizen participation in local government affairs. Whereas corruption is one of the serious challenges, all the three observers have only shown that corruption in local governments is a result of failure to provide accountability for public resources. This observation does not delve deep enough to show whether failed accountability directly affects local governments' implementation.

\section{The unrestrained creation of new districts}

Citizen participation is affected by the continued creation of new districts, making participation difficult and politicising all actions by government. As a result of district creation, small participation units start representing class, ethnic group and linguistic interests. By inference, the proliferation of unnecessary districts is directly matched by the proliferation of direct obstacles to inclusive citizen participation. Nsamba fails to justify whether new districts were exclusive compared to older districts in terms of citizen participation. It remains unclear whether district fragmentation has any negative impact on the level of and implementation.

\section{Overcoming the challenges to effective citizen participation}

Some practical measures have been proposed in order to counter the challenges to effective citizen participation:

\section{Inclusion of all citizens in determining local priorities}

Local needs at the parish councils ought to be prioritised by all citizens, especially those in the higher councils such as the district and the municipality (Ansell, Doberstein, Henderson, Siddiki \& Hart, 2020). This move is expected to address the challenge of dominance by males as well as those with lower levels of education and low incomes. Prioritising local needs would thus not just call for the district and municipal leaders to take note of the parish proposals but, more importantly, to have those proposals captured in the final budget framework. Nonetheless, it is important to note that the view presented by Ansell et al (2020) focuses on the parish level and fails to reveal whether the same strategy can be adopted at the higher local government levels, such as Uganda or Hoima municipality.

\section{Improving the capacity of local leaders}

Chairpersons who convene village meetings should demonstrate real capacities to mobilise residents, focus meetings, organise meeting venues, target major social citizens and ensure proper documentation of local council meeting proceedings (Vidyattama, Sugiyarto \& Sutiyono, 2020). Although the proposed strategies could have some positive impact, the scholar does not indicate how district-based challenges could fit in the same path and raise citizen participation. 


\section{Actualising the influence of women in local councils}

Women's influence in local councils can be actualised through fair rules, policies, practices, and local councils' friendly organisational cultures. The two scholarly views were raised over 10 years ago and conditions have changed, given the several amendments made to the Local Governments Act 1997. In addition, the local government information that is otherwise passed through personal networking can be channelled through the official mechanisms, which will reduce collusion among local officials (Ntola, 2020). The proposal by Ntola calls for women's economic empowerment as a raison deter for increased participation of women in the local governments.

\section{Translating local council transactions into local languages}

Lower local council 'business' can be transacted in the local languages within specific areas since most local councillors are not highly educated despite being good local leaders (Mwesigwa, 2015). Whereas the use of local languages in all local councils would be a positive development, the move would risk being used to create the problem of "districtism" or tribalism, which is detrimental to national integration.

\section{Dealing with the degree of local conflict of interest}

Reducing conflicts of interest as well as central government's reluctance to cede power and resources can be tamed so that local government plans and budgets are actualised (Owisiak, Greig \& Diehl, 2021). The two scholars' proposals fail to reveal the practical means through which conflicts of interest can be tamed among local governments. In addition, the scholars fail to show whether any reduction in the conflicts of interest would increase the scale of and implementation in local governments. Third, the two scholars' issues seem to have been overtaken by time, thus requiring us to examine the most recent developments in and strategic interventions by devised by developing countries.

\section{Conclusion}

Citizen participation is key to quality service delivery as well as enhancing local democracy seeing that it facilitates citizen empowerment and responsibility - a reason why the international community, especially the World Bank has put greater emphasis to citizen participation as one of the principles of good governance and sustainable development.

\section{Limitation and study forward}

This study took a desk research and the actual opinions from selected citizens may be parallel to the conclusions obtained in this review.

\section{References}

Ahn, J., and Rho, T. (2021). The effect of customer participation in service industry on encounter satisfaction by the development of relationship. Journal of global scholars of marketing science, 31(1), 94-120, doi: 10.1080/21639159.2020.1808806

Ansell, C., Doberstein, C., Henderson, H., Siddiki, S., and Hart, P. (2020). Understanding inclusion in collaborative governance: a mixed methods approach. Policy and society, 39(4), 570-591. DOI:10.1080/14494035.2020.1785726

Arkorful, V.E., Lugu, B.K., Hammond, A., and Basiru, I. (2021). Decentralisation and citizens' participation in local governance: does trust and transparency matter? An empirical study. Forum for development studies, doi: 10.1080/08039410.2021.1872698

Arnstein, S.R. (2019). A ladder of citizen participation. Journal of the American planning association, 85(1), 24-34. doi: 10.1080/01944363.2018.1559388

Bedigen, W., Mdee, A., Temlong, R., Thorley, L., and Tshomba, P. (2020). The failure of externallydriven advocacy initiatives to contextualise sub-Saharan 'marginalised women'. Development in practice, doi: 10.1080/09614524.2020.1836129

Benstead, L.J. (2019). Do female local councillors improve women's representation? The journal of the Middle East and Africa, 10(2), 95-119, doi: 10.1080/21520844.2019.1580085 
Binnema, H., and Michels, A. (2021). Does democratic innovation reduce bias? The G1000 as a new form of local citizen participation. International journal of public administration, doi: $10.1080 / 01900692.2020 .1863425$

Board, E. (2008). Introduction to Rethinking MARXISM, Rethinking Marxism, 20(4), 539-545, doi: $10.1080 / 08935690802299405$

Bohn, C. (2019). Preference transformation through 'green political judgement formation'? Rethinking informal deliberative citizen participation processes. Critical review of international social and political philosophy, doi: 10.1080/13698230.2019.1698122

Bulthuis, S.E., Kok, M.C., Amon, S., Agyemang, S.A., Nsabagasani, X., Sanudi, L., Raven, J., Finn, M., Gerold, J., Tulloch, O., and Dieleman, M.A. (2021). How district health decision-making is shaped within decentralised contexts: a qualitative research in Malawi, Uganda and Ghana. Global public health, 16(1), 120-35, doi: 10.1080/17441692.2020.1791213

Byekwaso, N. (2010). Poverty in Uganda. Review of African political economy, 37(126), 517-25. Retrieved Feb. 8, 2021, from http://www.jstor.org/stable/25767302

Campe, R. (2020). Actor, orator, person: the representation of passion and the passion of representation in Hobbes' Leviathan. Law \& literature, 32(2), 207-21, doi: 10.1080/1535685X.2020.1763590

Carvallo, A., Pinto-Coelho, Z., and Seixas, E. (2019). Listening to the public - enacting power: citizen access, standing and influence in public participation discourses. Journal of environmental policy \& planning, 21(5), 563-76, doi: 10.1080/1523908X.2016.1149772

Connolly, J.M., Klofstad, C., and Uscinski, J. (2020). Administrative burdens and citizen likelihood to seek local public services: the case of hurricane shelters. Public performance \& management review, doi: 10.1080/15309576.2020.1818588

Corrigan, T. (2017). (Rep.). South African institute of international affairs. Doi: 10.2307/resrep25907

Deligiaouri, A., and Suiter, J. (2021). Evaluation of public consultations and citizens' participation in 2015 better regulation agenda of the EU and the need for a deliberative e-rulemaking initiative in the EU. European politics and society, 22(1), 69-87, doi: 10.1080/23745118.2020.1718285

Dixon, R., and Elson, T. (2019). Should councils collaborate? Evaluating shared administration and tax services in English local government. Public money \& management, 39(1), 26-36, doi: 10.1080/09540962.2019.1537704

Dodeigne, J., Jacquet, V., and Reuchamps, M. (2020). The attractiveness of local and national list labels: the role of socio-economic inequalities on the success of electoral lists. Local government studies, doi: 10.1080/03003930.2019.1677625

Dulhunty, A. (2020). Gendered isolation, idealised communities and the role of collective power in west Bengal self-help group. Gender, place \& culture, doi: 10.1080/0966369X.2020.1754167

Falanga, R. (2020). Formulating the success of citizen participation in urban regeneration: insights and perplexities from Lisbon. Urban research \& practice, 13(5), 477-99. Doi: 10.1080/17535069.2019.1607895

Falguera, X.C., Prieto-Flores, O., and Torruella, Q.B. (2020). Local consultations on public space management: between political legitimation and citizen empowerment. Space and polity, doi: $10.1080 / 13562576.2020 .1768061$

Feng, X., and Li, Q. (2020). Poverty alleviation, community participation, and the issue of scale in ethnic tourism in china. Asian anthropology, 19(4), 233-56, doi: 10.1080/1683478X.2020.1778154

Fisher, A., and Fukuda-Parr, S. (2019). Introduction - data, knowledge, politics and localising the SDGs. Journal of human development and capabilities, 20(4), 375-385, doi: 10.1080/19452829.2019.1669144

Forrest, S.A., Trell, E., and Woltjer, J. (2021). Emerging citizen contributions, roles and interactions with public authorities in Dutch pluvial flood risk management. International journal of water resources development, 37(1), 1-23, doi: 10.1080/07900627.2019.1701999

Forsberg, N. (2019). From self-reliance to that which relies: Emerson and critique as self-criticism. Educational philosophy and theory, 51(5), 498-507, doi: 10.1080/00131857.2017.1389271

Fridy, K.S., and Myers, W.M. (2019). Challenges to decentralisation in Ghana: where do citizens seek assistance? Commonwealth \& comparative politics, 57(1), 71-92, doi: $10.1080 / 14662043.2018 .1514217$ 
Gaber, J. (2019). Building 'a ladder of citizen participation. Journal of the American planning association, 85(3), 188-201, doi: 10.1080/01944363.2019.1612267

Gare, A. (2020). After neoliberalism: from eco-Marxism to ecological civilisation, Part 1, Capitalism nature socialism, doi: 10.1080/10455752.2020.1811363

Gohori, O., and Van der Merwe, P. (2021). Tourism and community empowerment: the perspectives of local people in Manicaland province, Zimbabwe. Tourism planning \& development, doi: $10.1080 / 21568316.2021 .1873838$

Hadden, J., and Bush, S.S. (2020). What's different about the environment? Environmental INGOs in comparative perspective. Environmental politics, doi: 10.1080/09644016.2020.1799643

Hambleton, R. (2019). The new civic leadership: place and the co-creation of public innovation. Public money \& management, 39(4), 271-79, doi: 10.1080/09540962.2019.1592908

Hossain, M., and Roy, P.K. (2019). Does democratic local governance facilitate local economic development? Evidence from Bangladesh. Local government studies, 45(6), 827-47, doi: 10.1080/03003930.2019.1583561

Ianniello, M., Iacuzzi, S., Fedele, P., and Brusati, L. (2019). Obstacles and solutions on the ladder of citizen participation: a systematic review. Public management review, 21(1), 21-46, doi: $10.1080 / 14719037.2018 .1438499$

Juntunen, M., and Lehenkari, M. (2021). A narrative literature review process for an academic business research thesis. Studies in higher education, 46(2), 330-42, doi: $10.1080 / 03075079.2019 .1630813$

Katusiimeh, M. (2015). The non-state provision of health services and citizen accountability in Uganda. Africa today, 62(1), 85-105, doi:10.2979/africatoday.62.1.85.

Khurshid, A. (2020). Love marriage or arranged marriage? Choice, rights, and empowerment for educated Muslim women from rural and low-income Pakistani communities. Compare: A journal of comparative and international education, 50(1), 90-106, doi: 10.1080/03057925.2018.1507726

Kim, J., and Sun, M. (2020). The implementation and potential effects of teacher evaluation under local control. School effectiveness and school improvement, doi: 10.1080/09243453.2020.1841657

Lang, C. (2020). Workforce diversity policies in practice: drivers and barriers in local administrations. Ethnic and racial studies, 43(11).1961-80. Doi: 10.1080/01419870.2020.1754444

Liao, Y., and Ma, L. (2019) do professional association make a difference? Linking municipal managers' association participation and attitudes toward citizen participation. Public management review, 21(12), 1824-47.

Makara, S., Rakner, L., and Svasand, L. (2009). Turnaround: the national resistance movement and reintroduction of a multiparty system in Uganda. International political science review, 30(2), 185-204, retrieved Feb. 8, 2021 from http://www.jstor.org/stable/25652898

Manyak, T., and Katono, L. (2011). Impact of multiparty politics on local government in Uganda. African conflict and peacebuilding review, 1(1). 8-38, doi: 10.2979/africonfpeacrevi.1.1.8.

Maryunani, S.R. (2019). Community empowerment as a means in promoting local products: a case study in Bandung, Indonesia. Journal of promotion management, 25(3), 439-51, doi: 10.1080/10496491.2019.1557821

Matarrita-Cascante, D., Lee, J.H., and Nam, J.W. (2020). What elements should be present in any community development initiative? Distinguishing community development from local development. Local development \& society, 1(2), 95-115, doi: 10.1080/26883597.2020.1829986

Mazrui, A. (1970). Leadership in Africa: Obote of Uganda. International journal, 25(3), 538-564, doi: $10.2307 / 40200856$.

McCandless, A., and McPherson, G. (2020). Promoting tangible and intangible hidden cultural heritage: local communities influencing civic decision-making and international cultural policy. International journal of cultural policy, doi: 10.1080/10286632.2020.1822348.

McGovern, R., and Thorne, P. (2020). Citizens assemble: a study on the impact of climate reporting in the Irish media 'media', 'during' and 'after' the citizens' assembly on 'how the state can make Ireland a leader in tackling climate change'. Irish political studies, doi: $10.1080 / 07907184.2020 .1811970$ 
McKnight, M.L., Gibbs, B.G., Sanders, S.R., Cope, M.R., Jackson, J.E., and Park, P.N. (2019). Small towns and urban centres: the relationship of distance and population size to community satisfaction. Community development, 50(4), 389-405, doi: 10.1080/15575330.2019.1682020

Michels, A., and De Graaf, L. (2017). Examining citizen participation: local participatory policymaking and democracy revisited. Local government studies, 43(6), 875-81, doi: $10.1080 / 03003930.2017 .1365712$

Moehler, D. (2006). Participation and support for the constitution in Uganda. The journal of modern African studies, 44(2). 275-308. Retrieved Feb. 8, 2021, from http://www.jstor.org/stable/3876158

Mpiima, D.M., Manyire, H., Kabonesa, C., and Espiling, M. (2019). Gender analysis of agricultural extension policies in Uganda: informing practice? Gender, technology and development, 23(2), 187-205, doi: 10.1080/09718524.2019.1657610

Muriisa, R. (2008). Decentralisation in Uganda: prospects for improved service delivery. Africa development, 33(4), 83-96. Retrieved February 8, 2021, from http://www.jstor.org/stable/24484010

Musenze, I.A., and Sifuna, M.T. (2020). Development and validation of a total quality management model for Uganda's local governments. Cogent business \& management, 7(1). Doi: 10.1080/23311975.2020.1767996

Mwanika, K., State, A.E., Atekyereza, P., and Osterberg, T. (2020). Colonial legacies and contemporary commercial farming outcomes: sugarcane in eastern Uganda. Third world quarterly, doi: $10.1080 / 01436597.2020 .1783999$

Mwesigwa, D. (2013). Citizen participation in policy formulation and implementation in local governments: a case of Hoima district. A Doctoral thesis submitted to the school of social sciences, Nkumba University, Uganda.

Mwesigwa, D. (2015). English language, local languages, or both? Analysing the effect of language proficiency on councillor involvement in local council discussions. Loyola journal of social sciences, XXIX(2). 209-30.

Nakayi, R. (n.d). Local governance in Uganda. Administrative law and governance project Kenya, Malawi and Uganda.

Nguyen, C.V., Giang, L.T., Tran, A.N., and Do, H.T. (2021). Do good governance and public administration improve economic growth and poverty reduction? The case of Vietnam. International public management journal, 24(1), 131-61, doi: 10.1080/10967494.2019.1592793

Ntola, S.Y. (2020). South Africa's governance perspective on the Indian Ocean rim association's (IORA) focus area on women's economic empowerment. Agenda, 34(4), 98-111, doi: 10.1080/10130950.2020.1799714

Owsiak, A.P., Greig, J.M., and Diehl, P.F. (2021). Making trains from boxcars: studying conflict and conflict management interdependencies. International interactions, 47(1), 1-22, doi: 10.1080/03050629.2021.1848827

Patrucco, A.S., Agasisti, T., and Glas, A.H. (2020). Structuring public procurement in local governments: the effect of centralisation, standardisation and digitisation on performance. Public performance \& management review, doi: 10.1080/15309576.2020.1851267

Przeybilovicz, E., Cunha, M.A., Geertman, S., Leleux, C., Mchels, A., Tomor, Z., Webster, W.R., and Meijer, A. (2020). Citizen participation in the smart city: findings from an international comparative study. Local government studies, doi:10.1080/03003930.2020.1851204

Ragauskas, R., and Thames, F. (2020). Cross-tier personal gains in mixed electoral systems. Journal of elections, public opinion and parties, doi: 10.1080/17457289.2020.1778008

Reidy, D.A. (2020). Rawls, law-making and liberal democratic toleration: from theory to political liberalism to the law of peoples. Jurisprudence, doi: 10.1080/20403313.2020.1800275

Richards, A.A.R., Jacobs, J.M., Ivy, V.N., and Lawson, M.A., (2020). Preservice teachers' perspectives and experiences teaching personal and social responsibility. Physical education and sport pedagogy, 25(2), 188-200. doi: 10.1080/17408989.2019.1702939

Rochlitz, M., Kazun, A., and Yakovlev, A. (2020). Property rights in Russia after 2009: from business capture to centralised corruption? Post-soviet affairs, 36(5\&6), 434-450. DOI: 10.1080/1060586X.2020.1786777 
Rosen, J., and Painter, G. (2019). From citizen control to co-production. Journal of the American planning association, 85(3), 335-47, doi: 10.1080/01944363.2019.1618727

Rosen, J., and Painter, G. (2019). From citizen control to co-production. Journal of the American planning association, 85(3), 335-47, doi: 10.1080/01944363.2019.1618727

Simplican, S.C. (2019). Theorising community participation: successful concept or empty buzzword? Research and practice in intellectual and developmental disabilities, 6(2), 116-24. Doi: $10.1080 / 23297018.2018 .1503938$

Singh, K.K. (2020). Traditional gender ideology on boys' participation in biology post-GCSE. Journal of biological education, doi: 10.1080/00219266.2020.1757488

Sobande, F., Ferafull, A., and Brownlie, D. (2020). Resisting media marginalisation: black women's digital content and collectivity. Consumption markets \& culture, 23(5), 413-28, doi: 10.1080/10253866.2019.1571491

Sobane, K., Van der Merwe, C., and Shandu, B. (2020). The silence of South African health policies on the language barrier between healthcare providers and patients. Language matters, 51(3), 87107, doi: 10.1080/10228195.2020.1794017

Townsend, B.G., Chen, J.T.H., and Wuthrich, V.M. (2021). Barriers and facilitators to social participation in older adults: a systematic literature review. Clinical gerontologist, doi: $10.1080 / 07317115.2020 .1863890$

Tromp, R.E., and Datzbeger, S. (2019). Global education policies versus local realities. Insights from Uganda and Mexico. Compare: a journal of comparative and international education, doi: 10.1080/03057925.2019.1616163

Vidyattama, Y., Sugiyarto, S., and Sutiyono, W. (2020). Budget delay: between local capacity, bargaining or political interaction in three study cases. Bulletin of Indonesian economic studies, doi: 10.1080/00074918.2020.1812515.

Wagenaar, H., and Wenninger, F. (2020). Deliberative policy analysis, interconnectedness and institutional design: lessons from 'Red Vienna'. Policy studies, 41(4), 411-37, doi: $10.1080 / 01442872.2020 .1717456$

Yang, X. (2020). Assessment accommodations for emergent bilinguals in mainstream classroom assessments: a targeted literature review. International multilingual research journal, 14(3), 217 32, doi: 10.1080/19313152.2019.1681615

Yuan, M., and Schraufnagel, S. (2020). Two-dimensional legislative conflict: unique implications for the effectiveness of local councils. Local government studies, 46(5), 780-99, doi: 10.1080/03003930.2019.1667773

Zhang, X., and Lee, S. (2020). Clubs' environmentally responsible behaviour: the perspectives of club managers in North America. International journal of hospitality \& tourism administration, doi: $10.1080 / 15256480.2020 .1862015$ 